\title{
Paediatrica Indonesiana
}

\section{Apoptotic cell identification: An in-vivo study during induction treatment of childhood acute lymphoblastic leukemia}

\author{
Pudjo H Widjajanto, AJP Veerman, Sutaryo
}

\begin{abstract}
Background Acute lymphoblastic leukemia (ALL) in children has high cure rate but it can cause death due to the side effects of treatment or to the disease itself. Thus the evaluation on response of treatment is important and may predict the prognosis. Since apoptosis can be induced by chemotherapy, it is thought that the number of leukemic cells that undergo apoptosis may reflect drug sensitivity and cytoreduction rate, thus it may correlate with prognosis.

Objective To detect apoptotic cells in peripheral blood of children with ALL during the first week of treatment.

Methods We conducted a cross sectional study on 58 children with newly diagnosed ALL treated in Department of Child Health, Sardjito Hospital, Yogyakarta. Apoptotic cells were detected on smears of buffy coat made from peripheral blod and stained with May-Grunwald Giemsa. The apoptotic cells viewed under light microscope within 12 time points during 7 days after treatment started. Results Apoptotic cells were identified in 3 of 58 patients with index range of $4.2 \%$ to $36.2 \%$.

Conclusion Apoptotic cells can be detected in peripheral blood with simple method. The explanation of why not all blood smears viewed showed these cells need further study. It may due to the methods or the apoptotic process itself. [Paediatr Indones 2006;46:195-198].
\end{abstract}

Keywords: apoptotic cells detection, peripheral blood, treatment response, childhood acute lymphoblastic leukemia

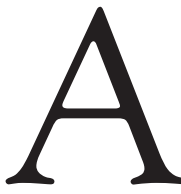

cute lymphoblastic leukemia (ALL) is the most common malignancy found in children in Indonesia as well as in the world. ${ }^{1}$ Although it has a high cure rate $(80-90 \%)$, if it is not treated, it can be fatal. ${ }^{2}$ In developing countries the mortality rate is still high, due to problems in diagnosis and limited access to chemotherapy. The diagnosis of ALL is based on the presence of leukemic cells (lymphoblasts) in circulation and definitely by the finding of more than $25 \%$ lymphoblasts in the bone marrow. At diagnosis, it is estimated that a number of $10^{12}$ lymphoblasts develops and burdens the body, while at the end of the induction phase about $10^{10}$ leukemic cells still persist. ${ }^{3}$ The higher the rate of cytoreduction, the more successful the regimen eradicates the malignancy, as has been proven by the response to one week monotherapy and by minimal residual disease studies.

Presented at The $3^{\text {rd }}$ SIOP-Asia Conference, Dhaka, February 26-28, 2004.

From the Department of Child Health, Medical School, Gajah Mada University, Yogyakarta, Indonesia (PW,S); Vrije Universiteit Medisch Centrum, Amsterdam, The Netherlands (AV).

Reprint request to: Pudjo H Widjajanto, MD, Department of Child Health, Medical School, Gadjah Mada University, Jl. Kesehatan No.1, Sekip Utara, Yogyakarta 55281, Indonesia. Tel. 62-274-587333 Ext 219/ 62-274-7176995; Fax. 62-274-583745. 
Many studies have shown a correlation of early response to treatment with the prognosis of childhood ALL. ${ }^{4-12}$ Unfortunately, studies to measure residual disease or apoptotic cells as response to treatment in ALL need laboratory facilities such as flowcytometer, or PCR and those are not always available in leukemia treatment centers in Indonesia. ${ }^{13-14}$ To solve this problem, we used a simpler, cheaper and reproducible method to detect leukemic cells that undergo apoptosis during the induction phase of treatment. The basic idea is that apoptotic leukemic cells have a specific morphology that could be viewed under light microscope.

Apoptosis or programmed cell death is a series of genetically controlled events which results in the removal of unwanted cells without tissue disruption. It can be activated by relevant stimuli and it is characterized by distinct morphological and biochemical features. Morphologically, apoptotic cells will present with nuclear chromatin condensation, budding of the plasma membrane and the production of membranebound apoptotic bodies. Since apoptosis is a way of cell death that can be induced by chemotherapy, ${ }^{15}$ it is thought that the number of leukemic cells that undergo apoptosis may reflect drug sensitivity and its role in cytoreduction may correlate with prognosis. Previous studies have shown that apoptotic leukemic cells could be identified in the circulation during ALL treatment and this has a correlation with leukemic cell reduction. ${ }^{16-17}$ The purpose of this study was to detect apoptotic cells in peripheral blood of children with ALL during the first week of treatment.

\section{Methods}

We conducted a cross sectional study on 58 children with ALL between 0-15 years old treated with Wijaya Kusuma ALL (WK-ALL) 2000 protocol in Department of Child Health, Sardjito Hospital, Yogyakarta from March 1999 to May 2001. The WK-ALL 2000 protocol was designed to meet the Indonesia situation, adopted from the experience of childhood ALL treatment in US and Europe consisted of 2 risk-based group i.e., standard-risk (SR) and high-risk (HR) patients. Patients whose WBC $>50,000 / \mathrm{ml}$, age $<1$ year or $>10$ years and showed involvement of any site in the body (mediastinal, testicle, central nervous sys- tem) at the time of diagnosis were classified into HR patients. The inclusion criteria were children with newly diagnosed ALL $\left(\mathrm{L}_{1}\right.$ or $\left.\mathrm{L}_{2}\right)$, without prior treatment for ALL, agreed to participate in this study. Informed consent was obtained from the parents or guardians.

Specimens of peripheral blood were taken during the first week of the 6 weeks remission induction phase consisted of one dose of intrathecal methotrexate adjusted to the age, dexamethasone $6 \mathrm{mg} / \mathrm{m}^{2} /$ day in SR and HR patients plus 1 dose of daunorubicin for HR patients. At the first day of treatment, a blood smear was made at 3 hourly intervals and repeated every 24 hours for the second to seventh day. The smears were made from buffy-coat prepared by centrifugation of finger tip blood in heparinized TerumoÒ capillary tubes at 2,500 rpm. Slides were stained with May-Grunwald Giemsa (Merck). Apoptotic cells were identified as small cells with nuclear condensation or apoptotic body formation (Figure 1). The apoptotic cells were calculated as apoptotic index, i.e., the percentage of apoptotic cells among 200 mononuclear cells counted under light microscope.

\section{Results}

Apoptotic cells were identified in 3 patients at different time point of studies stated before (Table 2). The apoptotic cells were observed at a range of $4.2 \%$ to $36.2 \%$. Two patients showed a sharp decrease of WBC in line with the decrease of lymphoblasts and increase of apoptotic cells percentage after 7 days treatment.

Table 1. Subject characteristics

\begin{tabular}{lcc}
\hline Characteristic & Number & $\%$ \\
\hline Sex & & \\
$\quad$ Male & 35 & 60 \\
$\quad$ Female & 23 & 40 \\
Age at diagnosis (years) & & \\
$\quad 0-1$ & 1 & 2 \\
$1-10$ & 52 & 90 \\
$10-15$ & 5 & 9 \\
FAB classification & & \\
L1 & 55 & 95 \\
L2 & 3 & 5 \\
Risk-group & & \\
$\quad$ High risk (HR) & 27 & 47 \\
$\quad$ Standard risk (SR) & 31 & 53 \\
\hline
\end{tabular}


Pudjo H Widjajanto et al: Apoptotic cell identification in childhood ALL

TABLE 2. BLASTS CELLS NUMBER REDUCTION AND APOPTOTIC INDEX

\begin{tabular}{|c|c|c|c|c|c|c|c|}
\hline \multirow[t]{2}{*}{ No } & \multirow[t]{2}{*}{ Identity } & \multirow[t]{2}{*}{ FAB risk } & \multicolumn{2}{|c|}{ d0-d7 } & \multicolumn{2}{|c|}{ Apoptotic index } & \multirow{2}{*}{$\begin{array}{c}\text { BMP } \\
\text { d0 (\%) }\end{array}$} \\
\hline & & & WBC (/ul) & Blast(\%) & & & \\
\hline 1 & Male, 2 yr & L1-SR & $11,400-3,600$ & $70-16$ & h9 & $=8.4$ & 99 \\
\hline 2 & Male, 14 yr, 4 mo & L1-HR & $93,600-12,200$ & $89-61$ & $\begin{array}{c}\text { h24 } \\
\text { h120 } \\
\text { h144 }\end{array}$ & $\begin{array}{l}=4.2 \\
=5.4 \\
=36.2\end{array}$ & 89 \\
\hline 3 & Male, $4 \mathrm{yr}, 9 \mathrm{mo}$ & L1-SR & $2,400-2,110$ & $11-0$ & h3 & $=11.8$ & 100 \\
\hline
\end{tabular}

$\mathrm{FAB}=$ French-American-British classification for acute leukemia; Risk=patients risk- grouping, $S R=$ standard risk and HR=high risk; d0$\mathrm{d} 7=$ peripheral blood before and day 7 after treatment started, WBC=white blood cell number, Blast=blast number as percentage of WBC; Apoptotic index=percentage of apoptotic cells in 200 mononuclear cells counted, $\mathrm{h} 9=9$ hours after treatment; BMP d0=blast number in bone marrow before treatment started
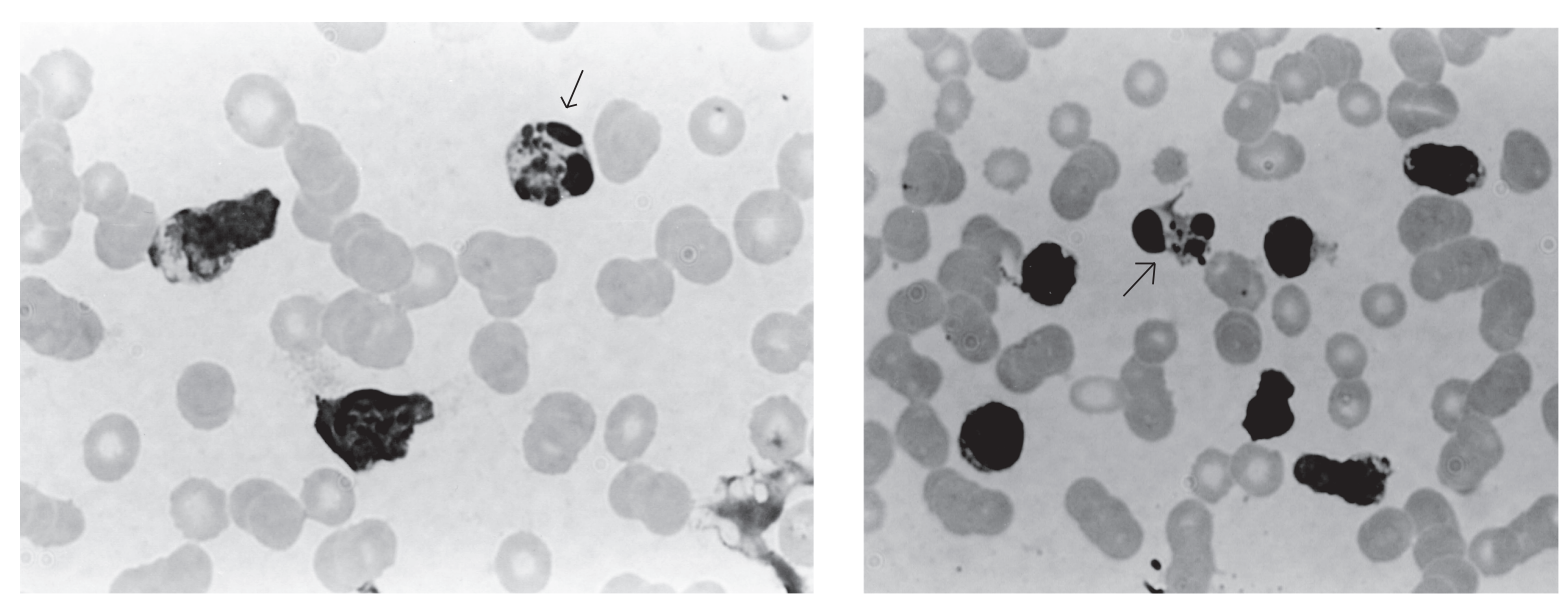

Figure 1. LeUKEMIC CELLS (LYMPHOBLAst) UNDERWENT APOPTOSIS AT 9 HOURS (A) AND 3 HOURS (B) AFTer TREATMENT STARTED IN PATIENT 1 AND 3, RESPECTIVELY.

NOTE THE SMALLER SIZE WITH NUCLEAR CONDENSATION AND APOPTOTIC BODY FORMATION.

\section{Discussion}

Until now only few studies had been performed to identify apoptosis during treatment in childhood ALL, especially using simple methods. Matsubara et al, ${ }^{16}$ found sharp declines of WBC and blast populations during chemotherapy, but failed to identify apoptotic cells in the circulation using May Grunwald-Giemsa staining. Tsangaris et $a l,{ }^{17}$ used nuclear staining with ethidium bromide under fluorescent microscop and found apoptotic cells in the circulation in various percentages, 24 hours after treatment. In comparison to the methods used by Tsangaris et al (1996), ${ }^{17}$ our method was simpler, using light microscop; May Grunwald-Giemsa staining was available easily in all hospitals, without fractionation process and no more reagents and facilities needed.

Our study shows that apoptotic cells could be identified morphologically in the circulation, with the buffy-coat as a better source of mononuclear cells or lymphoblasts than that of direct smear of a blood drop. During the first week of ALL treatment only sporadical apoptotic cells were recognizable in the peripheral blood, although the number of leukemic cells decreased sharply. The explanation of why we didn't find those cells in all smears or in the other 55 patients is still unclear. It may come from the situation where the apoptotic cells have been rapidly removed by phagocytes from the circulation or maybe our methods were not sensitive enough to detect small numbers of those cells in the circulation. Another possibility is there is certain machinery that 'prevent' apoptosis detection in vivo.

In conclusion, our results showed that apoptotic cells can be detected with simple method from circulation, especially on slides obtained from buffy coats. However, in most patients no apoptotic cells were seen, though the number of leukemic cells in the circulation decreased rapidly. Apparently, cell death through apoptosis is a process that takes place out- 
side the circulation, or apoptotic cells are rapidly taken out from the circulation.

\section{References}

1. Smith MA, Gloeckler Ries MA. Childhood cancer: Incidence, survival, and mortality. In: Pizzo PA, Poplack DG, editors. Principles and practice of pediatric oncology. Philadelphia: Lippincott William \& Wilkins; 2002. p. 1-12.

2. Pui $\mathrm{CH}$, Crist WM. Acute lymphoblastic leukemia. In: Pui CH, editor. Childhood leukemias. Cambridge: Cambridge University Press;1999.

3. Margolin JF, Steuber CP, Poplack DG. Acute lymphoblastic leukemia. In: Pizzo PA, Poplack DG, editors. Principles and practice of pediatric oncology. Philadelphia: Lippincott William \& Wilkins; 2002. p. 489-544.

4. Csoka M, Bocsi J, Falus A, Szalai C, Klujber V, Szende $\mathrm{B}$, et al. Glucocorticoid-induced apoptosis and treatment sensitivity in acute lymphoblastic leukemia of children. Pediatr Hem Oncol 1997;14:433-42.

5. Gajjar A, Ribeiro R, Hancock ML, Rivera GK, Mahmoud H, Sandlund JT, et al. Persistence of circulating blasts after 1 week of multiagent chemotherapy confers a poor prognosis in childhood acute lymphoblastic leukemia. Blood 1995;86:1292-5.

6. Gaynon PS, Bleyer WA, Steinherz PG, Finklestein JZ, Littman P, Miller DR, et al. Day 7 marrow response an outcome for children with acute lymphoblastic leukemia and unfavorable presenting features. Med Pediatr Oncol 1990;18:273-9.

7. Nachman J, Lukens J, Gaynon P, Magenis E, Wolff L, Sather $\mathrm{H}$, et al. Predictor of slow early response to BFM induction therapy in children and young adults with acute lymphoblastic leukemia. A report from children cancer group (CCG). Blood 1990;80(Suppl I):257a.

8. Rautonen J, Hovi L, Siimes MA. Slow disappearance of peripheral blast cells: An independent risk factor indicating poor prognosis in children with acute lymphoblastic leukemia. Blood 1988;71:989-91.

9. Sandlund JT, Harrison PL, Rivera G. Persistence of lymphoblasts in bone marrow on day 15 and day 22 to 25 of remission induction predicts a dismal treatment outcome in children with acute lymphoblastic leukemia. Blood 2002;100:43-7.

10. Schrappe M, Reiter A, Riehm H. Cytoreduction and prognosis in childhood acute lymphoblastic leukemia. J Clin Oncol1996;14:2403-6.

11. Schultz KR, Massing B, Spinelli JJ, Gaynon PS, Wadsworth L. Importance of the day 7 bone marrow biopsy as a prognostic measure of the outcome in children with acute lymphoblastic leukaemia. Med Ped Oncol 1997;29:16-22.

12. Steinherz PG, Gaynon PS, Breneman JC, Cherlow JM, Grossman NJ, Kersey JH, et al. Cytoreduction and prognosis in acute lymphoblastic leukemia-the importance of early marrow response: Report from the childrens cancer group. J Clin Oncol 1996;14:389-98.

13. Tsangaris GT, Stathopoulou FT. Development of a quantitative method for the study apoptosis in peripheral blood. In vivo1996;10:435-44.

14. Schuler D, Szende B, Borsi JD, Marton T, Bocsi J, Magyarossy E, et al. Apoptosis as a possible way of destruction of lymphoblasts after glucocorticoid treatment of children with ALL. Pediatr Hematol Oncol 1994;11:641-9.

15. Kerr JFR, Winterford CM, Harmon BV. Apoptosis, its significance in cancer and cancer therapy. Cancer 1994;73:2013-26.

16. Matsubara K, Kubota M, Adachi S. Induction of apoptosis in childhood acute lymphoblastic leukemia by chemotherapeutic agents: Failure to detect evidence of apoptosis in vivo. Eur J Hematol 1994;52:47-52.

17. Tsangaris GT, Moschovi M, Mikraki V. Study of apoptosis in peripheral blood of patients with acute lymphoblastic leukemia during induction therapy. Anti cancer 1996;16:3133-40. 